\title{
Landscapes of the Prehistoric Veneto, Italy. A Plurality of Local Identities Reflected in Cult and Landscape Perception
}

\author{
Sarah De Nardi \\ UCL Institute of Archaeology
}

\begin{abstract}
This paper explores issues concerning local identity, landscape awareness and social space within the Veneto region in northeast Italy in late prehistory (c. $8^{\text {th }}$ century BC to Romanisation in the $2^{\text {nd }}$ century $\mathrm{BC}$ ). The theory underpinning this paper and the author's research owes much to human geography, in endeavouring to 'rediscover' a 'sense of place' in landscape archaeology, drawing upon data from votive deposits, cemeteries and settlements in the Veneto region. In the search for place-specific significance, this paper will bring to the fore the nonuniform development and local variations in the material culture of the 'Veneti', traditionally identified as a single homogeneous ethnic and social unit, and suggest ways to avoid risky generalisations.
\end{abstract}

\section{Keywords}

Landscape, prehistoric Italy, prehistoric religion, sacred landscape.

\section{Introduction}

The relationship between people, landscape and the gods is central to my thesis, and this paper will focus on the theoretical problems arising when forcing an all-encompassing model onto the diverse extent of cultural and social phenomena across the region known as the Veneto in northeast Italy in late prehistory (c. $8^{\text {th }}$ century BC to Romanisation in the $2^{\text {nd }}$ century BC).

Traditionally, the study of Italic people (including the inhabitants of the Veneto) has relied heavily on Classical sources, namely Greek and Roman geographers and historians such as Strabo and Pliny the Elder (Malnati 2003: 11-13). This is a problematic approach because the views and perception of the authors was biased and often politically motivated. Nor do we know whether or to what extent the local people described in these accounts actually recognised themselves in these descriptions, or whether they were accurate portrayals of pre-Roman peoples' ways of life, especially when described by later (i.e. Roman) authors. This approach remains the main bias in modern Italian academia, and until recently Classical sources were taken at face value in the creation of Italic identities.

In contrast my research focuses exclusively on archaeological evidence pertaining to the Iron Age Veneto, and only draws upon written sources to support my theoretical and methodological findings. More specifically no adequate descriptions of Venetic landscapes and people-landscape interaction can be found in Classical sources (Capuis 1993: 15 ff; Malnati 2003: $16 f f$.).

In the search for place-specific significance I will outline the non-uniform development and local variations in the material culture of the 'Veneti', traditionally identified

Papers from the Institute of Archaeology 18 (2007): 39-56 
as a single homogeneous ethnic and social unit and will suggest ways of eliminating biases in research and interpretation. Settlements and cemeteries are discussed first, followed by cult places and material culture and finally overall patterns of landscape interaction.

It is to be expected that distinct regional identities should develop in this vast region, encompassing the Alpine milieu of the Cadore in the north at the border with Austria to the Adriatic coastline to the southeast via the Po plain and the piedmont belt (see Figs.1 and 2).

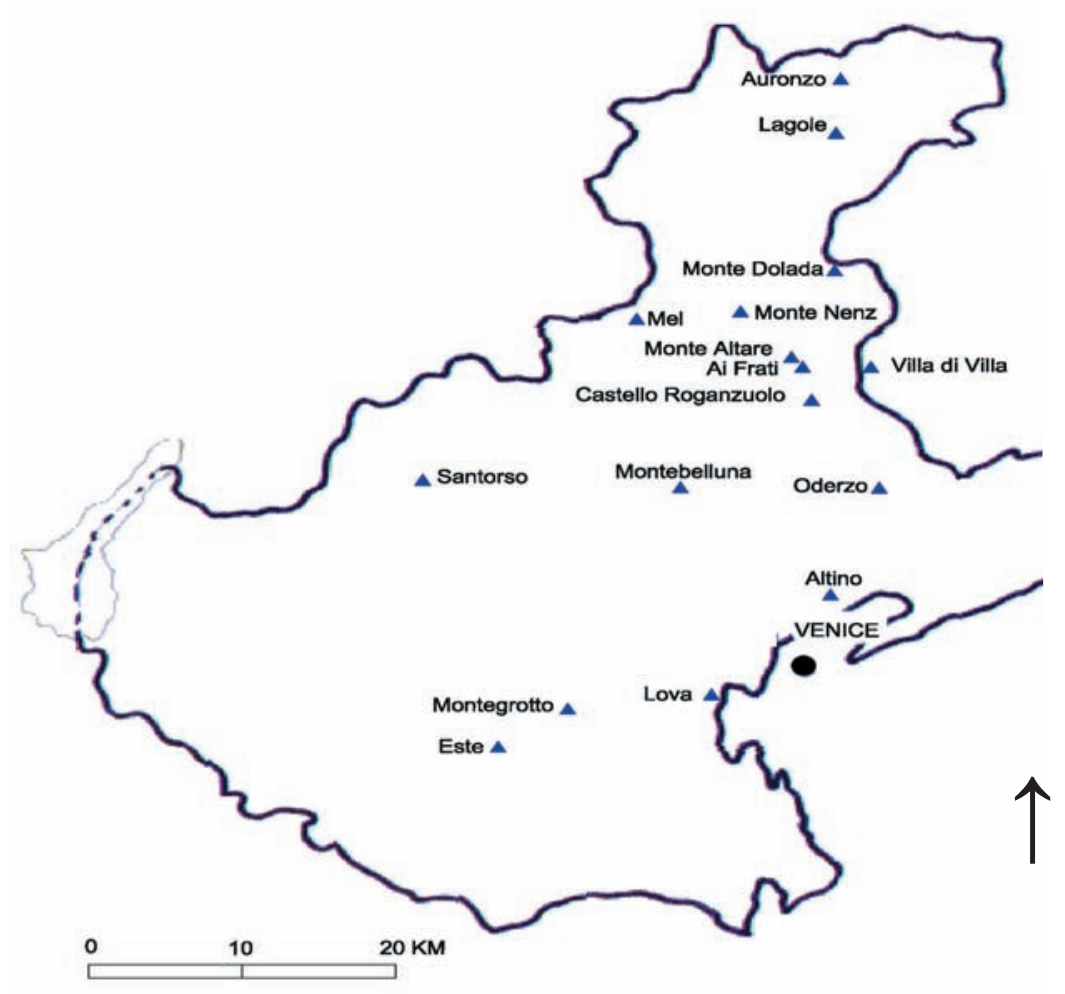

Figure 1. The Veneto. 

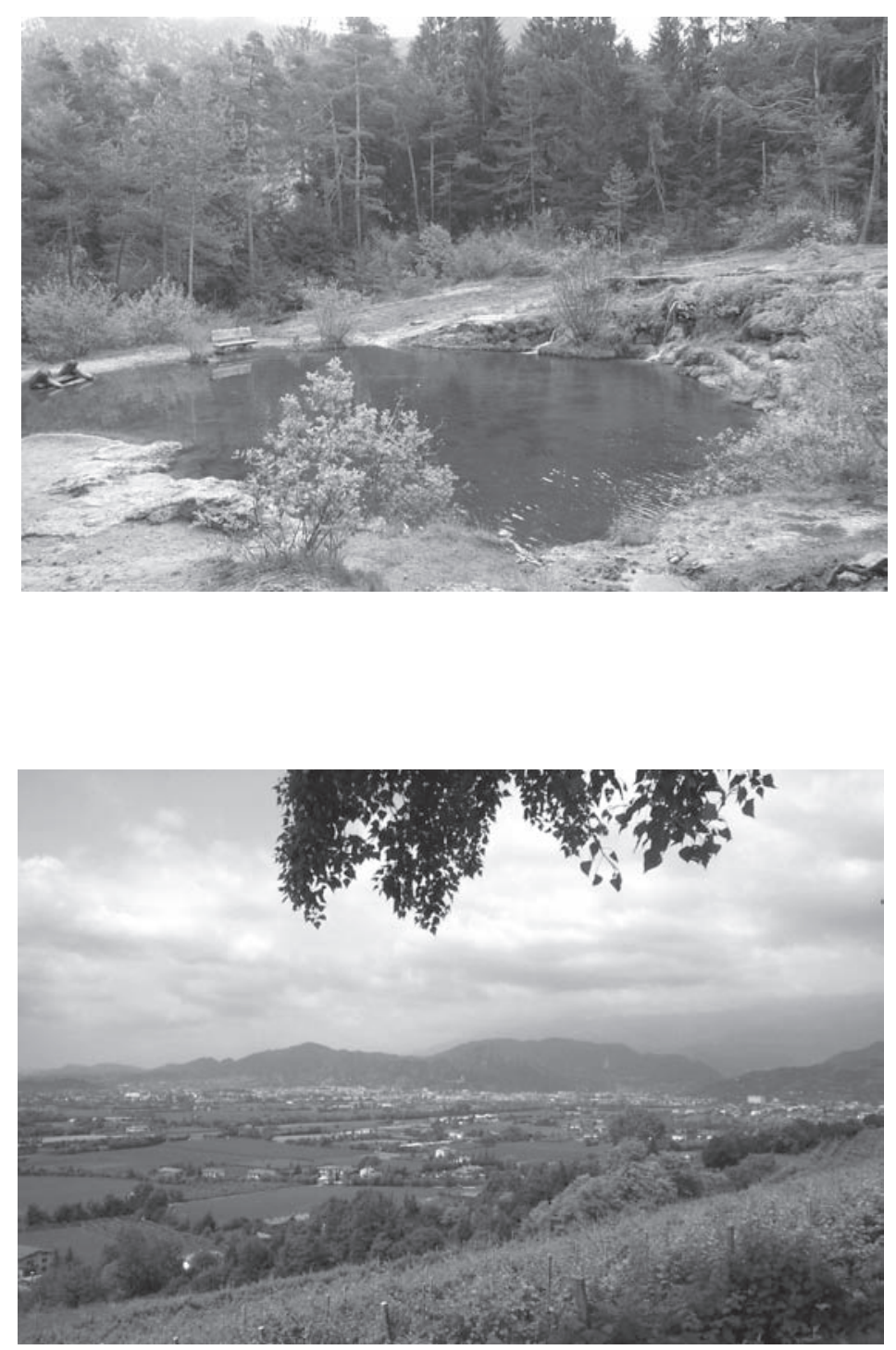

Figure 2. Venetic landscapes. Top: Lagole in the Alps. Bottom: The Trevisco piedmont. Photographs by the author. 


\section{Settlements and Cemeteries}

The pattern of Venetic settlements and cemeteries is patchy. Outlining the beginnings and development of local identities is problematic, as is the establishment of a consistent cultural sequence for the territory as a whole.

The development of Early Iron Age centres stemmed primarily from independent local stimuli and followed patterns previously established by Bronze Age centres (Bianchin Citton 2003: 24): thus, Este and Padua surged to the rank of central places in the Early Iron Age after the decline of the Bronze Age foci of Frattesina and Montagnana-Borgo San Zeno in the $9^{\text {th }}$ century BC (Capuis 1993). It is also commonly recognised that Iron Age Padua developed along the lines of a Late Bronze Age settlement (Bianchin Citton 2003: $25 \mathrm{ff}$.).

Recent excavations have determined the existence of other centres such as: the 'castellieri' of the nearby Friuli region; a recently discovered settlement associated with the tumuli of Mel in the upper Piave valley; Castion d'Erbè and Gazzo Veronese in the west; Montebelluna and Oderzo in the middle Piave Valley and Concordia in the northern Venetian hinterland (Ruta Serafini 2003: 58). Evidence of earlier or contemporary occupation of other parts of the Veneto can be potentially compared with Este, although the often unpublished or incomplete data pose problems in the understanding of Venetic settlements.

Moreover, there is not the same continuity in other places that can be observed in the Po plain. Certain sites in the north and east cannot be traced back to the Bronze Age; so how do we trace the initial development of eastern and northern sites? There are two complicating factors: the geographical context of sites - first and foremost the changing landscape of the lagoon and the woodland of the piedmont and Alpine regions (De Nardi forthcoming) and marginal landscapes (both lagoon and mountains) which pose logistical problems due to land morphology and woodland cover. In the southern lagoon, for instance, we find a substantial monumentalised cult place (Lova) established just before, or at the start of, Romanisation in the $3^{\text {rd }}-2^{\text {nd }}$ centuries BC. Although multiple deposition episodes suggest large-scale use of the site by a variety of worshippers, there are no settlements in its environs. This could have been caused by the shifting shape of the lagoon, reclaimed as early as the Roman period and throughout the centuries until modern times (Bonomi 2001: $247 \mathrm{ff}$.). Secondly, much of the evidence for settlements in the north and east has never been published systematically, and some never outside local specialist journals (Arnosti 1993, 1996b).

Another puzzle is posed by the site of Montebelluna in the central piedmont. Here we have evidence of three, possibly four, large cemetery areas yielding prestigious grave goods, and a potters' quarter, but no settlement has yet been unearthed, possibly owing to inconsistent archaeological discoveries in the late $19^{\text {th }}$ - early $20^{\text {th }}$ centuries when excavation techniques were still underdeveloped and the focus of archaeology was essentially on an archaeology of death, that is, cemeteries (Nascimbene 2003: 35). 
Data pertaining to settlements are virtually absent in the Alpine area, although this is probably due to the morphology of the mountainous landscape. The only substantial settlement is Mel, a site consisting of an extensive scatter of dwellings dated to the $6^{\text {th }}-3^{\text {rd }}$ centuries BC and located 20 minutes' walk from the Mel tumuli. Further north still, in the Alpine Cadore, cult evidence is rich but funerary and settlement data seem to have been obliterated. Moreover, even in the Roman period we do not find the systematic settlement pattern we encounter down in the valleys or in the piedmont, despite these places being along communication routes between the Hallstatt and La Tène areas and the southern regions.

In summary, scholars have placed great emphasis on the role of Este and Padua in the development of Venetic culture, and the development of urbanism is no exception: they ascribe the rise and development of centres such as Montebelluna and Vicenza to the influence of Este and Padua and attribute their rise and significance to their need to establish redistribution foci, territorial place-markers and links with Alpine transits (Locatelli 2003a: 46). However, Venetic centres were likely to function quite autonomously throughout their life: it is not plausible to attribute the initial stimulus of proto-urbanism and internal organisation solely to one or two centres that would not necessarily have been comparable topographically and/or geographically.

\section{Cemeteries}

In terms of funerary data, the issues identified above apply to much of the Veneto. Overall, it is Este and Padua that have supplied most of what is known of the mortuary record in the region, but we must bear in mind that very rarely, and only very recently, have other cemeteries elsewhere in the traditionally Venetic area been explored systematically. Thus, the hiatus between Atestine and other Venetic cemeteries is such that the former materials and sequences are well known and established, whereas much data from funerary contexts in the piedmont and Alpine milieus are lost. As a consequence, it is hard to make demographic, social and ritual inferences for this part of the territory. We could barely infer aspects of social stratifications, beliefs and mortuary trends from a sterile museum collection of materials unable to tell their story: whose graves they accompanied, why they were associated with particular individuals or classes, and where they were buried. With such a gap in the archaeological record, it is hard to decide how representative, typical or atypical the Este and Padua sequences are of 'Venetic' mortuary customs.

In the north, considerable damage had already been caused by early illegal excavations among the Mel tumuli when archaeologists set out to explore the site in 1959 (Capuis 1993: 45 ff.). Other local cemeteries, Cavarzano and Castellin di Fisterre, were also excavated at the end of the $19^{\text {th }}$ century by local amateurs, but few publications exist that enable scholars to learn much about the context and extent of the burials (Anon 1993: 63). In the Cadore, all that is left of the cemeteries of Pozzale and Lozzo are some of the grave goods displayed in a local museum, but their precise positioning and scale are debated. 
We are often forced to rely on antiquarian sources reporting the existence of cemeteries such as Ai Frati in Vittorio Veneto (Arnosti 1983: 18 ff.). This cemetery yielded aristocratic burials spanning a period from the $8^{\text {th }}$ to the $1^{\text {st }}$ centuries $\mathrm{BC}$ : one would expect a substantial settlement to match this location, but no data exist for habitation in the area before the Roman period aside from a scatter of isolated individual dwellings throughout the modern town. The site was unearthed and immediately destroyed during the construction of a $19^{\text {th }}$ century theatre without a systematic record of what had been found. However, some finds do survive, showing a wealth of La Tène fibulae, torques and iron axes (Arnosti 1996b: 52 ff.) (Fig. 3).
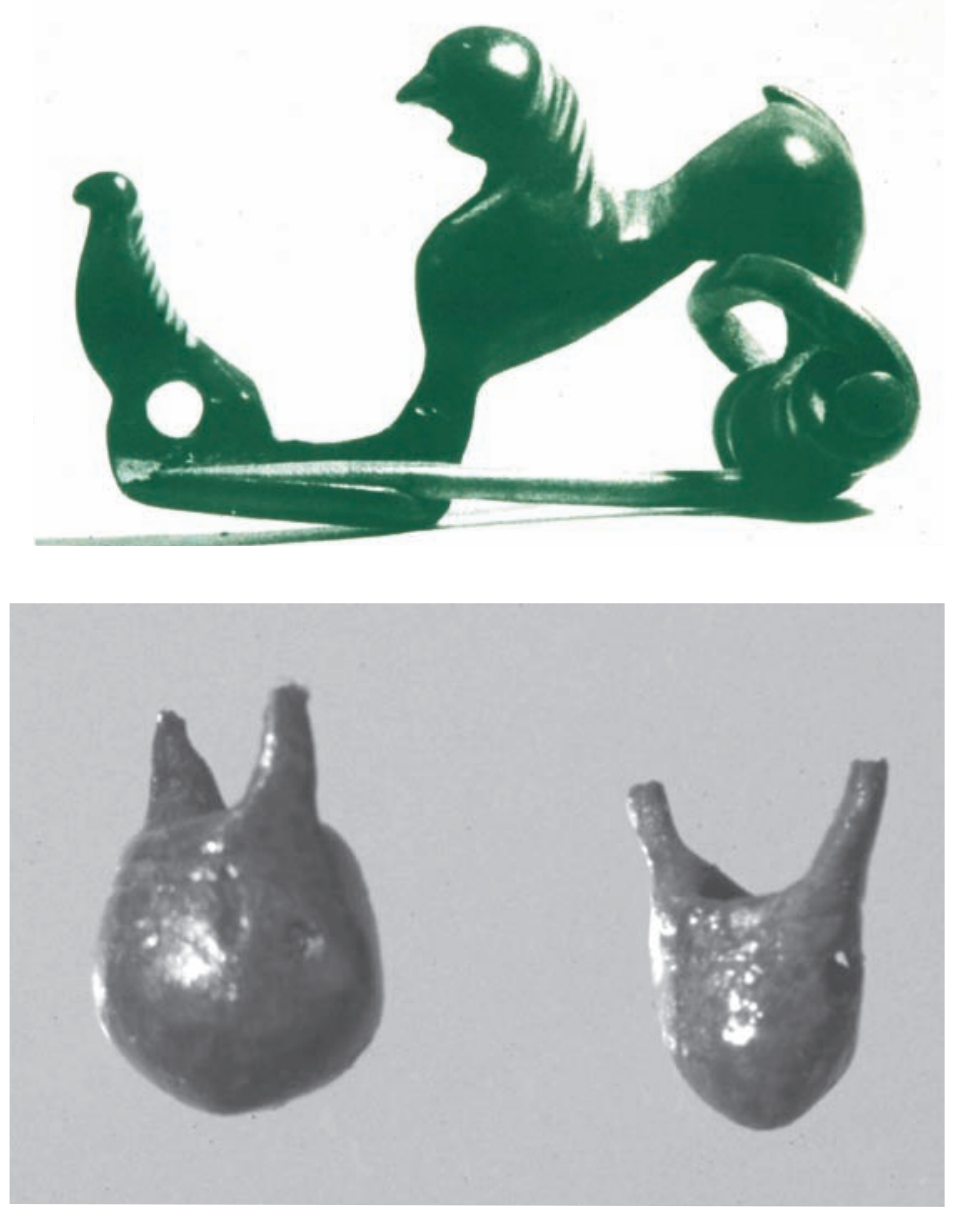

Figure 3. Grave goods from the Ai Frati cemetery, Vittorio Veneto. Top: sphinx fibula. Bottom: pendants. Photographs courtesy of the Gruppo Archeologico del Cenedese. 
Where did those who were buried at Ai Frati live? Early excavators, concerned with treasure and precious metals, probably unearthed hut floors or even more substantial remains of habitation but tossed the living debris aside as worthless, and proceeded to build on top of the remains of the Iron Age settlement nuclei. What remains are rare domestic pottery assemblages identified by local archaeologists during fieldwalking, which may or may not be representative of the actual settlement patterns in the area at the time of the use of the cemetery.

Local differences and variations in positioning and spatial relationships between sites can be observed, but one must bear in mind that local habitation and ritual patterns emerged from local stimuli and reflected the values of local inhabitants, and as such should not be exclusively considered in comparison with the Po plain. Here, the drive behind settlement strategies, urbanisation and ritual practices may have been caused by external influences or followed previously established patterns and local ancestral geographies.

\section{Variations in Cult Practices and Material Culture}

One of the most evident signs of local differentiation in material culture and social organisation is given by cult evidence. I will deal with a few issues regarding the relationship between people, cult practices and landscape here, focusing on artefacts and votive objects, local cults and landscape dynamics.

Across the Veneto, 43 cult places have been discovered, most of which are natural places where people deposited votive gifts to place-specific deities. Sacred places vary in relation to their positioning in the landscape, their spatial relationship with settlements, cemeteries and other significant sites, and by the treatment of the particular places in which they occur, i.e. whether they were visibly altered or left untouched.

Generally speaking, the inhabitants of larger Venetic centres such as Este and Padua worshipped deities appointed for the safety and welfare of the local community, and most cults within the bounds of the settlements had a strong link with the local aristocratic elite (initiation centres). Suburban cult places, situated to symbolically guard the inhabitants and local territory against the 'outside', reflect concerns with liminality (the boundary character of a place, be it actual or symbolic) and fertility, but the emphasis is less strong on large scale participation in cults (i.e. group offerings) and rather points to a more personal, almost one-on-one relationship between the worshipper and the deity (single/sporadic offerings).

Aside from the proto-urban and subsequently urban contexts of Este and Padua, and with the exception of Vicenza which displays similarities in cult practices to Padua (Zaghetto 2002), the archaeological record shows that the nature, extent, timescale and intensity of cult expressions and deliberate episodes such as ritual depositions, animal sacrifice and so on were extremely diverse throughout the ancient landscape (Capuis 1999). Patterns of landscape interaction and site positioning, and votive dedications, do vary substantially even in geographically limited areas. 
One criterion linking the iconography and purpose of votive objects and cults and landscape interaction in the region is the depiction or focus on natural elements in cult, or the depiction of special natural elements (e.g. peaks) in the material culture, which occurs at some sites but is absent from others. For instance, hilltop sacred sites in the northeast piedmont display similar site chronologies and votive types (laminae and bronzetti such as those in Figs. 4-6), but when we look closer we perceive discrepancies in votive iconography, their relative chronology and possibly unrelated cult recipients. At some places, such as Monte Altare and Col Castelir/Villa di Villa we find laminae cut in the shape of crenellations, peaks or oxen yokes: these have been interpreted in a variety of ways (stylised yokes, fortifications), but I believe they may be an 'idealised' portrayal of sacred peaks, seeing as they only occur at the two locations with the most prominent or visually striking hills, whereas the other cult places in the area had other primary concerns and cult foci, namely human and animal welfare and fertility and symbolic protection from neighbouring groups. See Fig. 5 for a comparative scheme showing the sacred sites, their positioning and types of votive objects found at various locations.
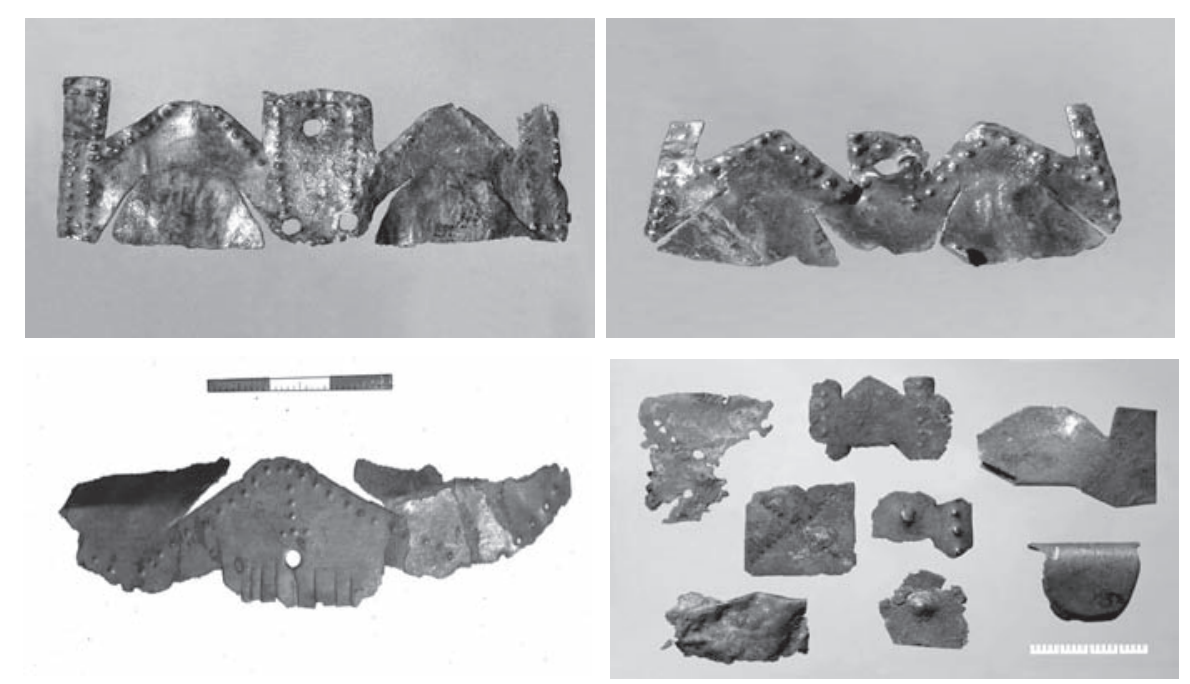

Figure 4. The stylised peak laminae. Top: Col Castelir. Bottom: Monte Altare. All photographs courtesy of the Gruppo Archeologico del Cenedese. 


\section{Site contexts and votive offerings}

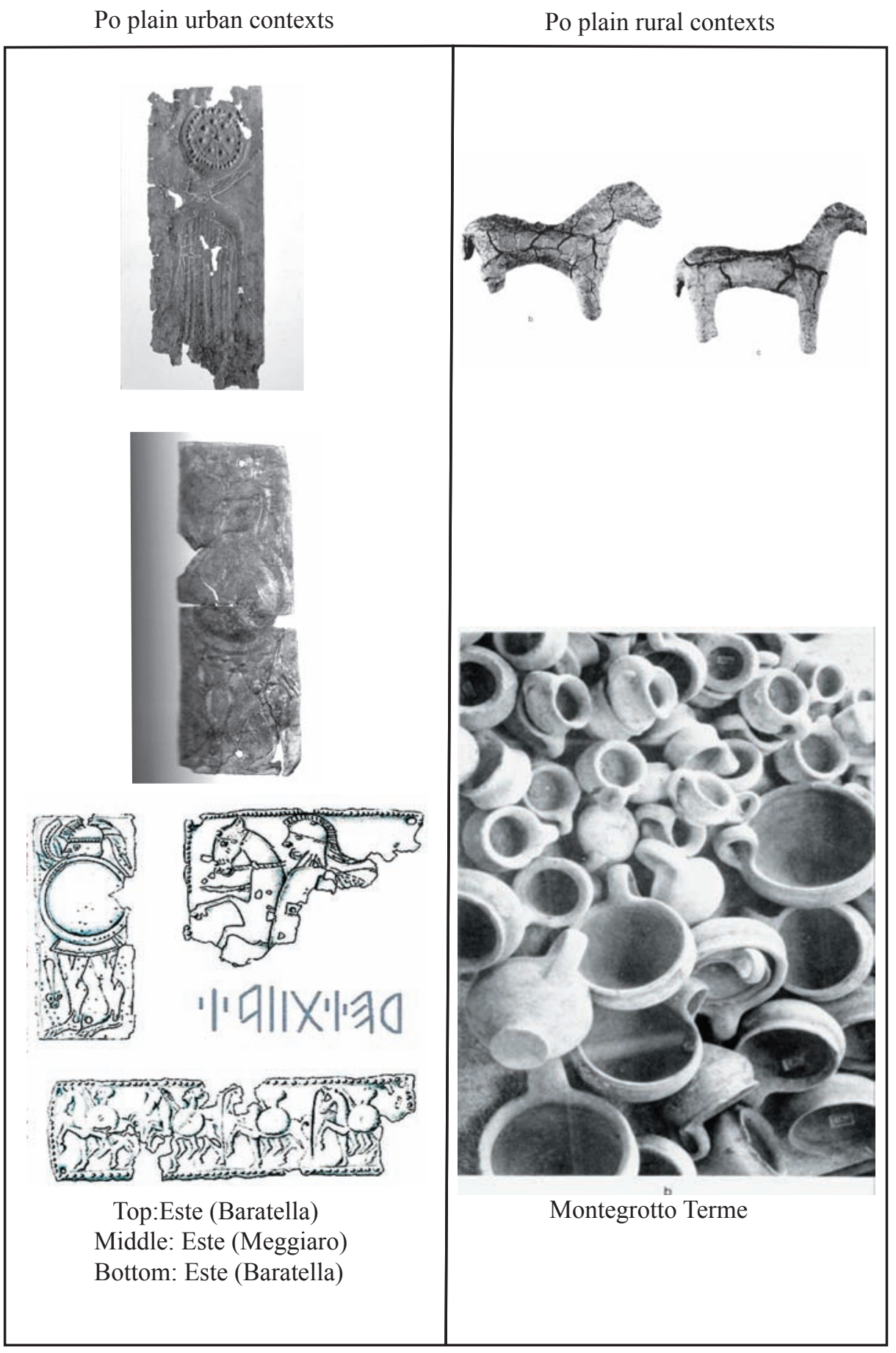


Mountains (rural context)

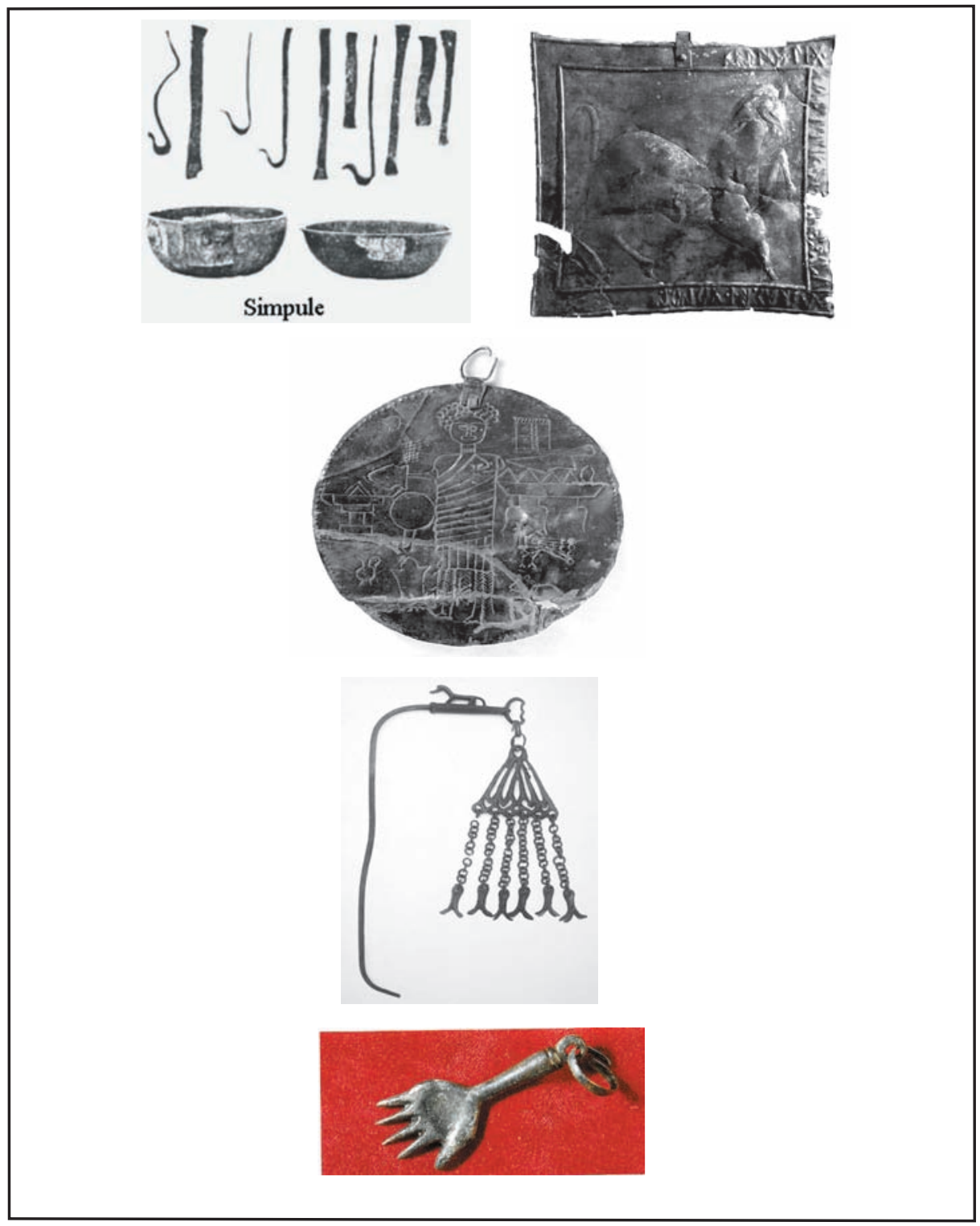

Figure 5. Different objects from landscape contexts of shrines and the votives.

Top, left and right: Lagole.

Monte Calvario-Auronzo

Trichiana Key/Monte Nenz

Bottom: Ponte nelle Alpi

Photographs courtesy of the Gruppo Archeologico del Cenedese. 
Lagoon sites such as Altino La Fornace and Lova di Campagnalupia vary in chronology, context, purpose and material culture, and ultimately reflect different local worshippers and identities. Altino was a geographically and symbolically liminal location, a locale tied to water redolent of ancestral values, being the earliest attested cult place in the Veneto, and walled as early as the $11^{\text {th }}-10^{\text {th }}$ centuries BC. This was a shrine for local worshippers but also a meeting point for different peoples, situated at a crossing of channels flowing into the Adriatic Sea, a strategic, emblematic point of approach to the settlement, a landmark for visitors and lagoon dwellers alike.

Lova was also a place-specific shrine: it belonged to the land and its milieu as much as to the inhabitants of the lagoon. The difference from Altino is that it was established during Romanisation, and abandoned shortly after Rome had established the Regio X. The chronology of Lova, together with the dedication of a uniquely local typology of bronzetti, and the offering of local fauna (and possibly flora) indicate a strong identity statement by local people, eager to establish their own cult place, to their own deity, in their own land.

In the northernmost sector of the region we have four or five recognised cult places: Lagole, Monte Nenz/Trichiana, Monte Calvario in Auronzo, Vallesella-Domegge and Valle di Cadore. Unfortunately the last two are only known by the objects stored in local museums, and their original location has not been recorded. Aside from their positioning in geographically liminal places, and the isolation from settlements, the landscape settings of the three sites are very different: a wooded watery place riddled with mineral springs in Lagole; a rocky spur jutting out of the side of a mountain in Monte Calvario; a hillock on a plateau framed by the Dolomiti in the case of Monte Nenz in Trichiana. If we are missing the local context of these cults, the local peculiarities and cult features, very little can be said about the significance of these boundary sites, and comparisons with the southern quarter of the Veneto alone are inadequate.
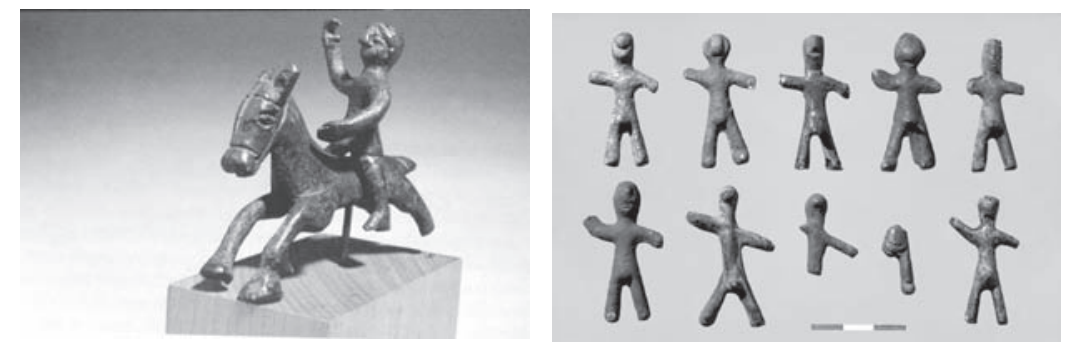

Figure 6. Different types of bronzetti: a selection. Left: Este (courtesy of the Museo Archeologico Nazionale di Este); right, from Monte Altare (courtesy of Giorgio Arnosti, GAC). 


\section{Material Culture}

The material culture and contexts of these sites are unique to each. Bronze figurines (bronzetti) from Lagole do not look like those from Este: they depict a different kind of worshipper or dedicator, and were donated for different reasons (Fig. 6). Those from rural contexts are more markedly ithyphallic, possibly indicating fertility concerns, whereas figurines from urban shrines depict men-at-arms or local elite members.

The lack of bronzetti from sites such as Monte Calvario and Presette (a site $3 \mathrm{~km}$ from Col Castelir yielding the same type of laminae but no bronzetti) demands a site-specific assessment of cult places and the motives behind their establishment and the local character of cult; similarly the few enigmatic votive objects from Monte Nenz (the Trichiana key, see Fig. 5) require yet another approach. The question to be asked is not whether a particular kind of offering was dedicated (i.e. bronzetti), but why we would expect to find it there: this was the initial reasoning behind my interpretation of the lack of stylised laminae from sites in the northeast piedmont (i.e. Castello Roganzuolo, Scomigo and Presette) which are very close to two main cult sites which have produced a large quantity of them.

I have offered my reading of these laminae above; as to the bronzetti, I argue that unlike laminae, which were meant to be appended, bronzetti could be laid out in sequences on flat surfaces and could recreate processions and military displays. Moreover, the very three-dimensional nature of figurines as opposed to two-dimensional laminae lends itself to a more hands-on experience, especially if the items were carried about one's person prior to dedication.

\section{Local Deities for Local Peoples}

The gods worshipped in the region appear to be place-specific and strongly characterised by local dedication contexts and types of votives. They also demanded very specific dedications. I suggest three possible scenarios:

a) Deities whose names and attributes occur more than once and names that are a oneoff and as such difficult to interpret, but generally thought to designate a deity.

b) Deities whose names occur at more than one site (one instance) and those perceived as 'place-specific' (the majority of 'known' deities).

c) Deities perceived to be male vs. deities thought to be female (with the exception of two instances where the name is ambiguous in gender and number).

Below I will briefly outline the role of literacy in our understanding of Venetic cult and deities.

\section{The Distribution of Literacy}

Analysis of literacy also indicates local variations of the 'same' Venetic language; the alphabet of Este differs from that of Padua, and ultimately from that of Lagole in the upper Piave valley, but writing overall was used predominantly for votive and funerary 
inscriptions (Whitehouse and Wilkins 2006: $533 \mathrm{ff}$.). That said, the evidence for writing in both the funerary and cultic realms reflected the spread and degree of literacy among the inhabitants of the Veneto: writing associated with cult practices occurred at Este-Baratella and Montegrotto in the Po plain, Vicenza, Lagole and Monte Calvario in Auronzo and, to a lesser extent, in Este-Meggiaro, Este-Caldevigo, Altino-La Fornace and Canevere in the lagoon, and in funerary contexts in Padua and Altino. The uneven distribution of writing may depend on several factors such as the fragmentary and incomplete nature of the archaeological record, different cult practices that may or may not have required written dedications, and the extent of literacy of different communities (Whitehouse and Wilkins 2006: 540).

The relative absence of inscriptions from cult places in the northeast piedmont, such as Monte Altare and the surrounding area raises interesting questions as to why the inhabitants of a region located in the middle of areas where literacy is markedly present (i.e. Este and Lagole) did not seem to adopt writing for themselves. If writing reached the Alps of Lagole, it would have had to pass through these areas, which further highlights the local individuality and peculiarity of the piedmont and its relative independence from the Po plain and the north.

An interesting comparison to the relative absence of literacy in the northeast piedmont, the boundary area with the La Tène area, is the occurrence of mantic inscriptions at sites in the northwest piedmont around and above Vicenza, the boundary area with the 'Raetic' Trentino. As mentioned above, writing is one of the ways in which scholars identified various deities and gained insights into their cults. Below is a review of the known characters in the Venetic 'pantheon'.

The best-documented deity is the goddess Reitia/Pora/Sainate-. The name Reitia seems to designate the act of writing, a sacred activity at this shrine (Whitehouse and Wilkins 2006: 536). Sainate-, an attribute of Reitia, could qualify her as the 'healer'. Reitia was worshipped in Este: Reitia and the epithet Sainate- are inscribed on many votive objects.

We only have three references to a so-called Altno- as a possible deity at Altino. According to Tirelli, the etymology of the so-called god's name bears a resemblance to the toponym Altino as known from Roman sources and even today (Tirelli 2003: 78).

The god Einaio- was worshipped on Colle del Principe-Caldevigo, a suburban shrine in Este, in no apparent connection with the cult of Reitia. We cannot infer much from a single occurrence of the name.

The suburban shrine of Este-Meggiaro yielded one inscribed lamina dedicated to a Heno[...] toi, interpreted as a deity, possibly a god concerned with coming-of-age and fertility rites judging by the iconography of the dedicated objects, consisting for the most part of laminae depicting warriors and of bones of pregnant sows and pig foetuses interred in ritual pits (Fiore and Tagliacozzo 2002: 190 ff.). 
Trumusiate-/Trimusiate- was worshipped in Lagole: one ongoing interpretation associates their etymology to a "wet or marshy location or place" (Marinetti in Gangemi 2003a : 89). Trumusiate was the object of dedication on numerous ladle bowls and ladle handles bearing the name: in the Roman period this deity (or these deities) became synchretised with Apollo the Healer, as witnessed by inscriptions (Fogolari 2001: 375).

The lakeside shrine of Montegrotto Terme yielded a single dedication to 'Hevissos' and one Latin reference to Aponus.

The shrine of Monte Calvario in Auronzo, one of the latest in date as it was established during Romanisation and continued throughout the Roman Imperial period yielded written dedications to deities known as the Maisteratorfos-, perhaps ancestors or territorial deities (Gangemi 2003b: 101).

Finally, the piedmont shrine of Col Castelir produced one inscribed lamina bearing 'Vesuta-' in the Venetic script (a goddess?), whilst ithyphallic bronzetti found at the site suggest a predominantly male representation.

\section{Patterns of Interaction with the Landscape}

In the south of the region people tended to prioritise settlement space and structure their daily lives around established boundaries and activity areas, hence the focus of cemeteries and shrine positioning in relation to the layout of the settlement area in Este and Padua; in these cases the sacred element either coincided with the dwelling sphere (domestic shrines) or pertained to the river as symbolic boundary (cf. Maioli and Mastrocinque 1992).

As a result of my fieldwork and interpretation I would argue that at rural or en route locales in the south of the region liminal or 'magical' (e.g. hot springs) natural landscape elements attracted cult activity and dedications, but local people chose not to alter these places with permanent structures, and relied on the striking visual features of the landscape to structure their experience of the sacred (this is the case at the unaltered sacred places of Montegrotto and Abano Terme). People's perception of striking natural features was strong enough not to demand the construction of structures to create a 'sense of place'. The lack of structures may also be due to the fact that these 'sanctuaries' were used by scattered local groups rather than a well-defined protourban community: unlike Este, the political statement of sanctuary building was not necessary.

In the east, cult places were strongly tied to the topographically and symbolically liminal character of the lagoon: this is suggested by the dedication of aquatic fauna and marine pebbles at both sites, although variations occur in terms of the function and chronology of the two places (cf. Bonomi 2001: $250 \mathrm{ff}$.). Settlements, on the other hand, of which we have only one example (Altino), occupied sandy banks in the middle of the lagoon, positioned in relation to canals leading out into the Adriatic Sea. Here, despite the less than well-defined territorial aspect of the lagoon sacred sites, local people decided to build permanent structures to lay claims to the land, and even reclaimed large portions of the lagoon to set up their cult places: hence the late but full scale monumentalisation 
(i.e. the construction of a permanent temple structure) of the shrine of Lova ( $2^{\text {nd }}$ century $\mathrm{BC}$ ) in the province of Venice, and the early structuring of the cult place of Altino La Fornace in separate activity areas for sacrifice and processions (the processional path that was periodically restored) (Tirelli 2003: 79).

In the piedmont the landscape element, taken to mean the physical morphology of the land and the livestock that were the livelihood of these people, predominates in the local perception of the sacred and is reflected in a local cosmology of high and prominent places. In the piedmont the element of liminality was reflected in places such as peaks and caves (Bocca Lorenza) and the offering of coins, that in the Alpine prehistory are found at places of passage to propitiate or give thanks for a safe journey through perilous or foreign landscapes (De Nardi forthcoming).

In the mountains, where the transalpine character of material culture is pronounced, local cults occurred at sacred natural places (Lagole and possibly Monte Calvario) and at boundary locales (the same two sites and Vallesella), where more 'central European' offerings prevailed: weapons, bronzetti depicting northern warriors and keys (Gambacurta 2003: 51). It is interesting to note how no landscape manipulation at these places occurred with the exception of the late Romanisation cult place of Monte Calvario, and how even the Romans, although worshipping certain locales (Lagole) until well into the $4^{\text {th }}$ century AD, did not 'disturb' significant local topography by monument building.

Overall it can be said that local geography and individual communities influenced the selection of suitable ritual locales: they vary substantially even in geographically restricted areas such as greater Este, greater Padua and the piedmont.

Place-specific diversity in burial customs and cult is mirrored in different positioning of sites, different criteria for ritual locations, different treatment of place and, ultimately, different cults.

\section{Conclusions}

A pattern emerges from sacred contexts across the region: ritual and cult in the north and east do not overlap with ritual, cult and site positioning in the south.

Despite a strong research bias towards sites in the south and east of the Veneto, it is clear from material culture and landscape context comparisons that sacred sites and cemeteries should be studied in their specific context, not bent to adapt to existing templates.

Overall, the way people interacted with places reflected their identity in that they imprinted, or chose not to imprint, their community-specific values in the selection of sites and interaction with their landscape: they expressed their attachment to the land by interacting and engaging with their surroundings in a variety of ways; they made themselves at home by creating a sense of familiarity in the landscape (cf. Craik 1986: $48,54-55)$. The extent of landscape use and perception suggested by the archaeological 
evidence for cult and mortuary sites, far from being homogeneous, indicates diverse local identities and interests rather than a uniform pattern of landscape interaction.

How then to redress the imbalance? In terms of the material culture proper, I believe an understanding of local processes can be achieved by assessing evidence for what objects were found compared with evidence for what objects were likely to be found, but were not, at ritual sites; this would also give an insight into possible choices/preferences/local trends for site positioning and people-landscape interactions. In terms of landscape use and perception, considering ideas and concepts stemming from human geography (e.g. Craik 1986; Mugerauer 1985; Relph 1981, 1985; Tuan 1977) could enhance and better contextualise the data we possess, and reveal the 'moods' and materiality of sacred objects and places.

I have briefly touched upon the issue of local identities and outlined the inconsistent weight of evidence pertaining to the archaeology of a land, a region, that is not merely a region, but a constellation of largely independent local communities spread over a vast area that today, as yesterday, hosts a variety of local identities, dialects and traditions. More attention needs to be paid to local peculiarities, to individual expressions of distinct groups of people going about their own lives, most of whom would have rarely travelled to Este to become 'imbued' with the values and customs of the Po plain. These 'marginal' identities cannot be ignored in an attempt to generate an all-encompassing pattern, or they risk to become repressed in the process. Different developments in the region should be identified at a local level, or where impossible (i.e. from lack of evidence or unknown artefact provenance), this should be explicitly identified as a problem affecting an overall understanding of the socio-cultural dynamics of the Veneti.

\section{References}

Anon. 1993. I Paleoveneti nel Bellunese. Verona: Cassa di Risparmio di Verona, Vicenza e Belluno.

Arnosti, G. 1983. Preistoria e Storia tra Piave e Livenza - Reperti Archeologici nel Museo del Cenedese di Vittorio Veneto (TV). Quaderni del Gruppo Archeologico del Cenedese 4, 2-44.

Arnosti, G. 1990. Il Nume Tutelare di Villa di Villa. Il Flaminio. Rivista di Studi StoricoArcheologici della Civilta' Montana delle Prealpi Trevigiane no. 5, 3-16.

Arnosti, G. 1993. Reperti Votivi e Santuari dei Paleoveneti nell'alto Cenedese. Il Flaminio. Rivista di Studi Storico-Archeologici della Civilta' Montana delle Prealpi Trevigiane no. 6, 55-82.

Arnosti, G. 1996a, Per Cenetam Gradiens. Appunti sulle Vie della Romanizzazione con Riferimento all'Antico Cenedese. Il Flaminio. Rivista di Studi Storico-Archeologici della Civilta'Montana delle Prealpi Trevigiane no. 9, 59-105.

Arnosti, G. 1996b. L'Età del Ferro nell'Antico Cenedese. Pamphlet, Circolo Vittoriese di Ricerche Storiche. Vittorio Veneto, 49-81.

Bianchin Citton, E. 2003. Le Origini: la Formazione della Civiltà Veneta nell'Età del Bronzo Finale (XII-X secolo a.C.), in Malnati, L. and Gamba, M. 2003 (eds.), I Veneti dai Bei Cavalli. Treviso: Canova, 2327. 
Bonomi, S. 2001. Il Santuario di Lova di Campagna Lupia, in Tirelli, M. and Cresci Marrone, G. 2001 (eds.), Orizzonti del Sacro: Culti e Santuari Antichi in Altino e nel Veneto Preromano. Rome: Quasar, 245-254.

Capuis, L. 1993. I Veneti: Società e Cultura di un Popolo dell'Età Preromana. Milan: Longanesi.

Capuis, L. 1999. Gli Aspetti del Culto: Tra Continuità e Trasformazione, in Tirelli, M. and Cresci Marrone, G. (eds.), Vigilia di Romanizzazione. Altino e Veneto Orientale tra II e I Secolo Avanti Cristo. Atti del Convegno a Venezia, San Sebastiano nel Giugno 1997, Vol. 11. Rome: Quasar, 153-170.

Craik, K. 1986. Psychological Reflections on Landscape, in Penning-Roswell, E.C. and Lowenthal, D. (eds.), Landscape Meanings and Value. London: Allen and Unwin, 48-63.

De Nardi, S. forthcoming. A Journey Through 'Hidden' or Forgotten Landscapes in the Northern Veneto. Patterns and Biases in Material Culture and Research Methods, in van Leusen, $M$. (ed.), Hidden Landscapes conference proceedings, Siena 25-27 May 2007.

Fiore, I. and Tagliacozzo, A. 2002. I Resti Ossei Faunistici, in Ruta Serafini, A. 2002 (ed.), Este Preromana: una Città e i suoi Santuari. Treviso: Canova, 185-197.

Fogolari, G. 2001. Lagole, Luogo di Culto fra i Luoghi di Culto Veneti, in Fogolari, G. \& Gambacurta, G. Materiali Veneti Peromani e Romani del Santuario di Lagole di Calalzo al Museo di Pieve di Cadore. Collezioni e Musei Archeologici del Veneto. Rome: Giorgio Bretschneider Editore, 371-378.

Gambacurta, G. 1999. Acqua, Città e Luoghi di Culto nel Veneto Preromano, Ocnus 7 179-186.

Gambacurta, G. 2003. I Circoli di Mel e la Chiave di Trichiana (BL), in Malnati, L. and Gamba, M. (eds.), 50-51.
Gangemi, G. 2003a. Il Santuario di Lagole di Calalzo di Cadore, in Malnati, L. and Gamba, M. (eds.), 88-90.

Gangemi, G. 2003b. Il Santuario in Località Monte Calvario di Auronzo di Cadore, in Malnati, L. \& Gamba, M. (eds.), 100-102.

Locatelli, D. 2003. La Necropoli di Montebelluna (TV), in Malnati, L. \& Gamba, M. (eds.), 74-75.

Maioli, M. G. \& Mastrocinque, A. 1992. La Stipe di Villa di Villa e $i$ Culti degli Antichi Veneti (con un Contributo di Giovanni Leonardi) Rome: Giorgio Bretschneider Editore.

Malnati, L. \& Gamba, M. 2003 (eds.). I Veneti dai Bei Cavalli, Treviso: Canova.

Malnati, L. 2003. Le Fonti Greche e Latine sull'Antico Popolo dei Veneti, in Malnati, L. \& Gamba, M. (eds.), 11-19.

Mugerauer, R. 1985. Language and the Emergence of Environment, in Seamon, D. and Mugerauer, R. 1985 (eds.), Dwelling, Place and Environment. Towards a Phenomenology of Person and World. New York: Columbia University Press, 51-70.

Nascimbene, A. 2003. Rituale Funerario, Tipologia e Corredi Tombali, in Archaiologia, Quaderni del Museo di Storia Naturale e Archeologia di Montebelluna, Issue $1,33-44$.

Relph, E. 1981. Rational Landscapes and Humanistic Geography. London: Croom Helm and Totowa, New Jersey: Barnes and Noble.

Relph, E. 1985. Geographical Experiences and Being-in-the-world. The Phenomenological Origins of Geography, in Seamon, D. And Mugerauer, R. 1985 (eds.), Dwelling, Place and Environment. Towards a Phenomenology of Person and World. New York: Columbia University Press, 15-32. 
Ruta Serafini, A. 2002 (ed.). Este Preromana: una Città e i suoi Santuari. Treviso: Canova.

Ruta Serafini, A. 2003. L'Organizzazione delle Città e la Definizione dei Territori, in Malnati, L. \& Gamba, M. (eds.), 57-60.

Tirelli, M. and Cresci Marrone, G. 1999 (eds.). Orizzonti del Sacro: Culti e Santuari Antichi in Altino e nel Veneto Orientale. Atti del Congresso, Venezia 1-2 dicembre 1999. Rome: Quasar.

Tirelli, M. \& Cipriano, S. 2001. Il Santuario Altinate in Località " Fornace", in Tirelli, M. and Cresci Marrone, G. 2001 (eds.) Orizzonti del Sacro: Culti e Santuari Antichi in Altino e nel Veneto Preromano, , Rome: Quasar, 37-60.

Tirelli 2003. Altino (VE): Il Santuario per Gli Emporoi, in Malnati, L. and Gamba, M. (eds.), 78-79.
Tuan, Yi-Fu 1977. Space and Place: The Perspective of Experience. Minneapolis: University of Minnesota Press.

Whitehouse, R. and Wilkins, J. 2006. Veneti and Etruscans: Issues of Language, Literacy and Learning, in Herring, E. et al. (eds.) Across Frontiers: Etruscans, Greeks, Phoenicians \& Cypriot: Studies in Honour of David Ridgway and Francesca Romana Serra Ridgway London: Accordia Research Centre, 531-548.

Zaghetto, L. 2002. Il Santuario di Vicenza, in Ruta Serafini, A. 2002 (ed.), Este Preromana: una Città e i suoi Santuari, Treviso: Canova, 306-310. 